\title{
After - Sales Service and Pricing as Determinants on Consumer Buying Decision in Automotive Industry Case Study: Porsche Kosova
}

\author{
Gent Abdullahu \\ Faculty of Economics, \\ University of Prishtina "Hasan Prishtina", \\ Prishtine, Kosovo \\ Ejup Fejza \\ Faculty of Mathematics and Natural Sciences, \\ University of Prishtina "Hasan Prishtina", \\ Prishtine, Kosovo
}

Doi: 10.36941/ajis-2020-0o21

\section{Abstract}

The automotive industry is considered one of the most positive industries in global technological development. Various manufacturers have built and developed automobiles not only to improve the transportation system but also to encourage environmental protection to the full automation of the transportation system. Kosovo doesn't have any production in automotive industry, but the trading of vehicles is growing every day more and more, where the buying decision is mostly taken by the price of the vehicle and after-sales services. Thus, the aim of this study is to analyze the role of after-sales services and pricing as determinants on consumer buying decision. For this purpose, we analyzed data gathered from Porsche Kosova sh.p.k., own internal research in Kosovo with 5870 customers over the years 2008-2019. Results show that beside pricing and after-sales services, there are other determinants which affect buyer decision making such are performance, life style, image and so on.

Keywords: after-sales services, pricing, performance, automotive industry, decision making.

\section{Introduction}

The automotive industry is considered one of the most positive industries in global technological development. Various manufacturers have built and developed automobiles not only to improve the transportation system but also to encourage environmental protection up to the full automation of the transportation system. Therefore, the field of marketing automotive trade and developing the services offered by the vehicles themselves offers significant potential in support of market competition. This situation causes manufacturers of different brands to develop different pricing strategies that offer competitive opportunities and advantages in the market. Increasing competition between vehicle manufacturers makes manufacturers constantly face with challenges as they need to change their production and marketing practices. This means that manufacturers must constantly be creative with the equipment and functions provided by vehicles. Despite the fact that a considerable amount of research has been conducted on after-sales vehicle and pricing policy in the automobile 
trading, such research in Kosovo has never been conducted and therefore the data on the Kosovo auto market continues to remain deficient. In addition to providing new insights into pricing strategies and after-sales services between specific vehicle brands, this study will also offer an approach of defining the Kosovo customer profile and influencing factors in brand selection. This data is to the benefit of stakeholders in their decision-making processes for the development of the automotive trade industry. The activity of certain brands within a single group, and in a competitive environment, is considered a relatively new development in the automotive industry. This has started as an idea of merging several brands under one common group to reduce production and operating costs. Today, many manufacturers that are part of a group share the same distribution network, the same product lines, and the same product development processes. Today, most of the brand models we have included in this study have the same platform or technical parts. This is also observed in models that do not compete in the same market segments. As an example: the Skoda Octavia model, though positioned for the middle class, shares most of the technical parts with Audi A3, a model that targets the "premium" segment of the market. The only differences we can notice with these manufacturers lie in the pricing and brand name strategy which defines the market segment where these brands want to operate. The brands which will be researched in this study are: Volkswagen, Skoda, Audi, Seat, and Porsche. These brands are represented in Kosovo through the authorized importer Porsche Kosova shpk. Porsche Kosova shpk is a company of the Austrian Porsche Group, one of the biggest and most successful private company in sales and after-sales in the world.

\section{$1.1 \quad$ Volkswagen in Kosovo}

The lack of studies on automobiles in the Republic of Kosovo leads to the lack of data on the number of Volkswagen vehicles in Kosovo. However, according to the latest data from a study by GAP Institute in Kosovo in 2015, there were $103687 \mathrm{VW}$ branded vehicles or $36 \%$ of total registered vehicles. Although present in the market with the Typeı / Beetle model, the brand's promotion and fame in the Kosovo market has been achieved with the Golf model. Given that this model was also manufactured within the Yugoslav Republic (1972 - 1992), the access to the Volkswagen for Kosovo citizens was easier with the Golf 1 and Golf 2 being the first modern vehicles in offer on the territory of Kosovo during the 7os, 8os and 9os from TAS ("Tvornica automobile Sarajevo" / "Sarajevo Vehicle Factory"). As strong and reliable vehicles, these models made the Volkswagen brand the most preferred brand in the Kosovo market. Sales before 2009 are not part of this study, due to the lack of accurate information regarding VW sales in Kosovo. VW sales in Kosovo from 2009 to 2018 are presented in the table below:

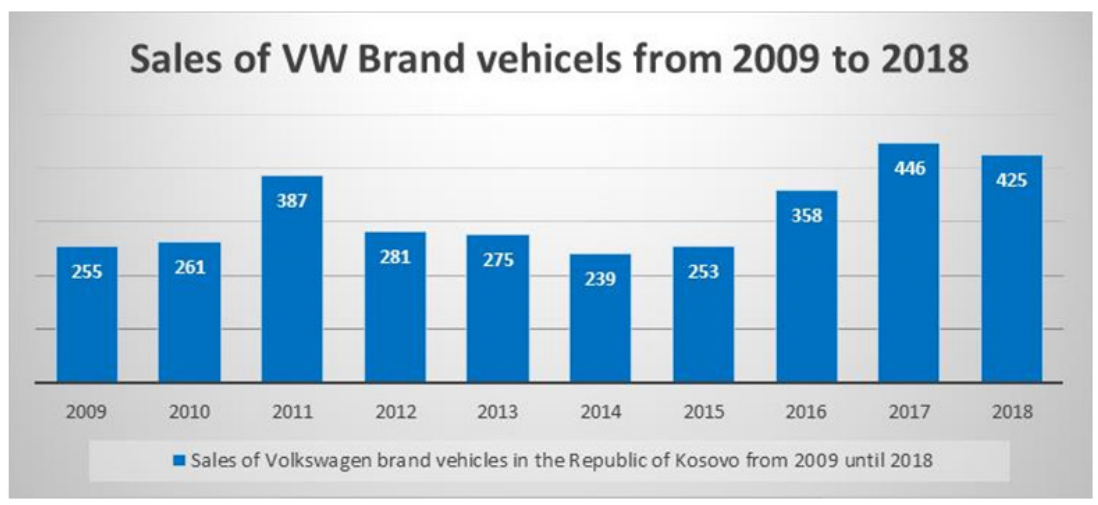

Figure 1. VW vehicle sales in Kosovo 2009-2018

Source: Porsche Kosova 


\subsection{Skoda in Kosovo}

As the sole official importer of the Skoda brand for the Republic of Kosovo, Porsche Kosova invested in improving the brand's image by promoting this brand as a quality product with reasonable cost and high durability. Characterized as a "low-priced Volkswagen", Skoda quickly began expanding into the Kosovo market, becoming the most used vehicle by Taxi companies interested in sustainable, reasonably priced vehicles. Since 2009 Skoda has had a steady increase in the number of vehicles delivered to the Kosovo market:

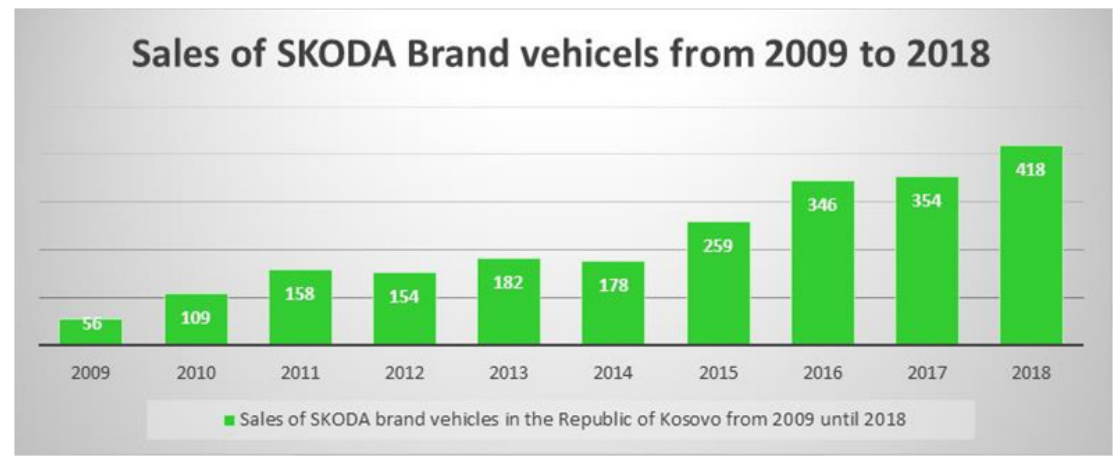

Figure 2: Skoda vehicle sales 2009-2018

Source: Porsche Kosova

\subsection{Audi in Kosovo}

In a market that is struggling to absorb high-end luxury products, Audi continues to grow year by year. According to the data obtained from Porsche Kosova, a total of 351 new Audi vehicles have been delivered in Kosovo since 2009, marking a significant increase in recent years.

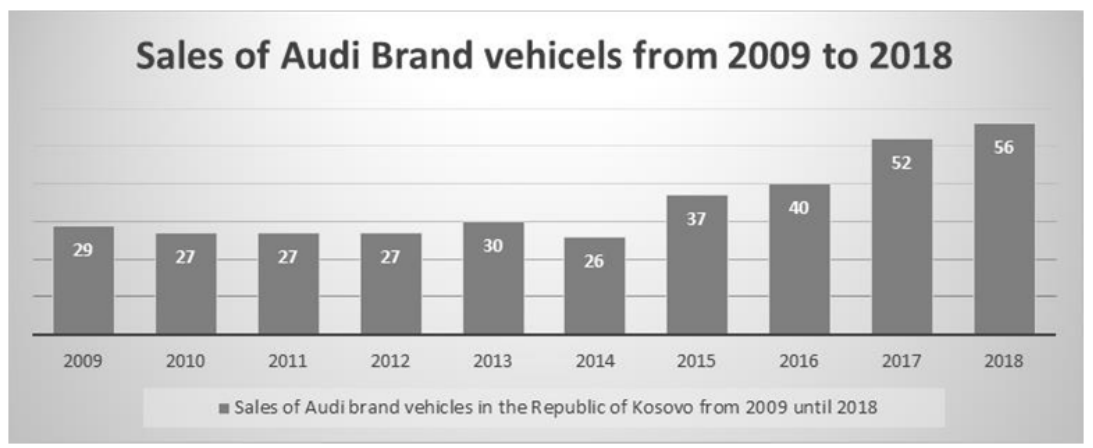

Figure 3: Audi vehicle sales 2009-2018

Source: Porsche Kosova

\subsection{Seat in Kosovo}

Being one of the smallest producers of VW Group, SEAT's presence was and continues to be low in the Kosovo market. Although some companies in post-war Kosovo imported the SEAT brand, the manufacturer did not have a serious representation until 2014, when Porsche Holding acquired the 
right to represent the brand in the territory of Kosovo. Thus adding another brand to the portfolio of brands represented by Porsche Kosova. Being a relatively unknown brand, SEAT registered symbolic sales over the years. However with the introduction of new models like the SEAT Arona and Ateca, the manufacturer is in the right direction to position itself in the Kosovo market by registering a record sale 46 new vehicles in 2018 .

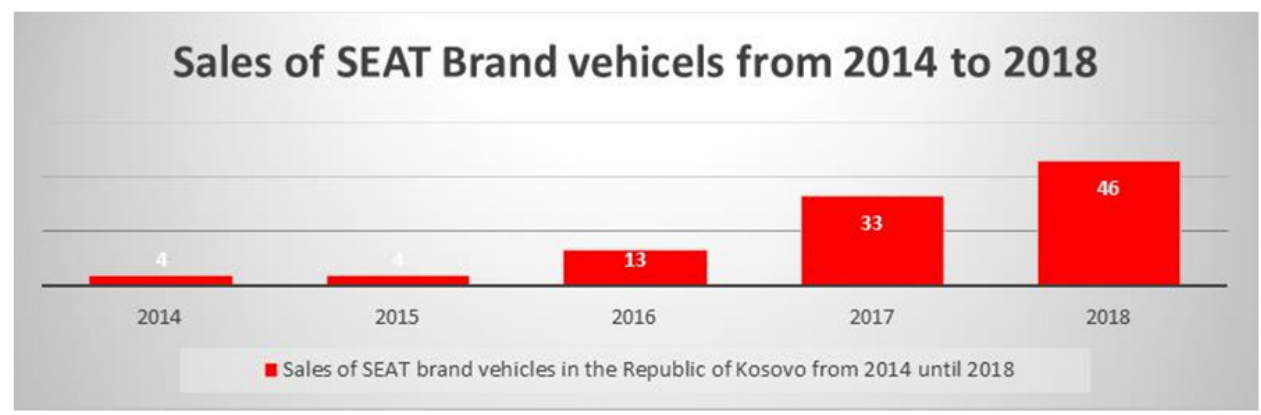

Figure 4: SEAT vehicles sale 2014-2018

Source: Porsche Kosova

\subsection{Porsche in Kosovo}

Since Porsche is a brand of exclusive and highly sporty vehicles, Porsche's presence is very small on our roads. In 2015, only 61 Porsche vehicles were registered in Kosovo. And the official representative Porsche Kosova sh.pk, from 2009 to 2018 has delivered a total of 25 new Porsche vehicles.

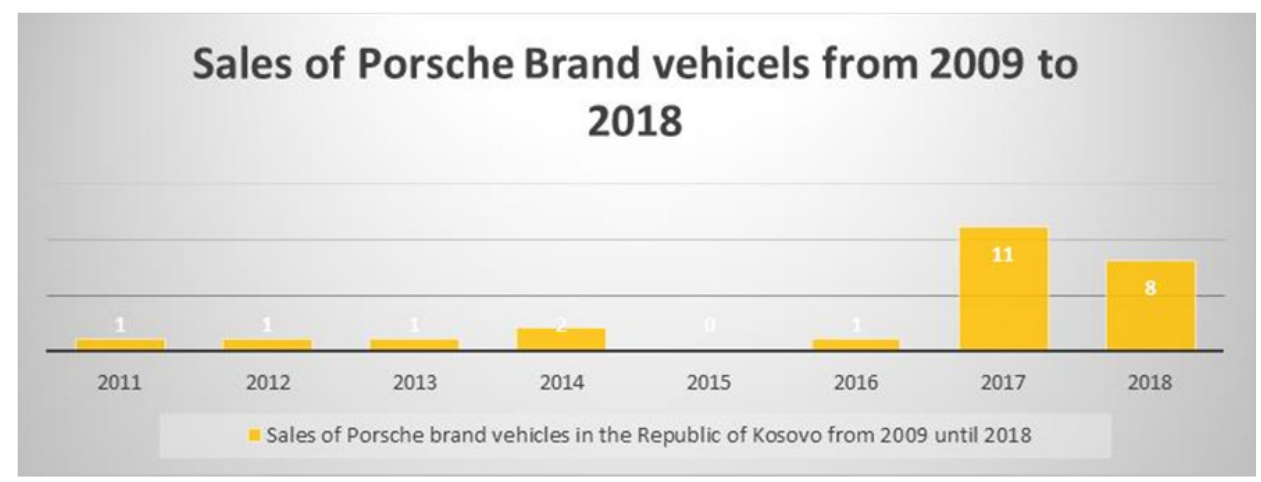

Figure 5: Porsche Vehicle sales 2009-2018

Source: Porsche Kosova

For each of these brands we can say they are in a good position in the Kosovo market in the segment they target, and within the group, based on the latest data, Volkswagen continues to dominate: 


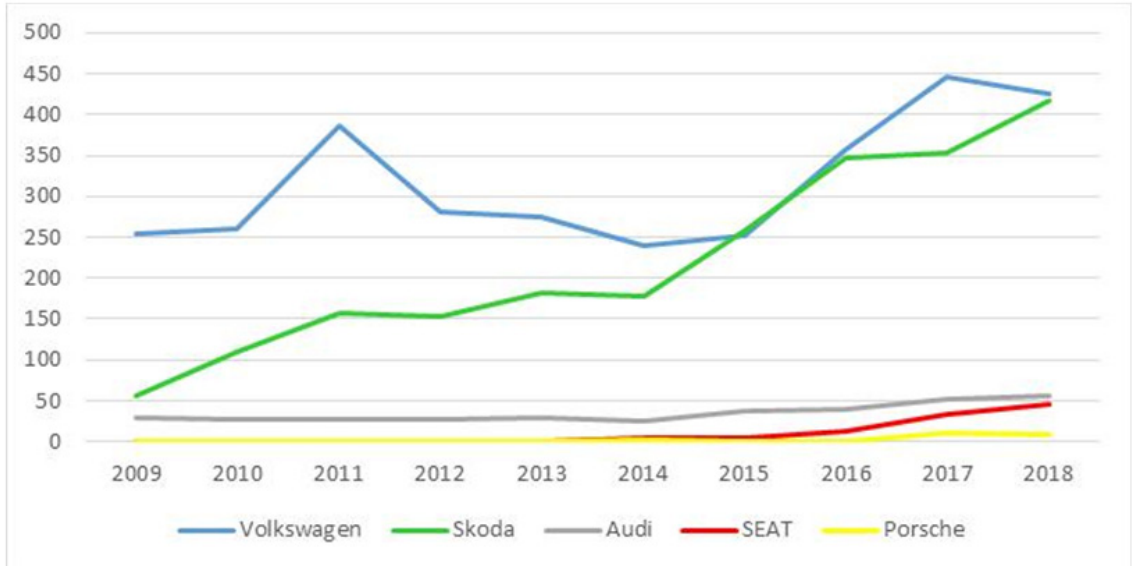

Figure 6: Sales of vehicles by brands

Source: Porsche Kosova

\section{Literature Review and Theoretical Background}

Different definitions about marketing and its role toward the customer satisfaction are provided. "Marketing is a social and management process through which individuals and groups gain what they need and want, through the creation, delivery and exchange of valuable products with others" (Kotler \& Keller, 2012). The American Marketing Association (2019) offers this formal definition that states: "Marketing is a process activity to create, communicate, deliver, and exchange offers that have value for customers. Offering and exchanging offers that have value to customers, partners and society at large. "Marketing strategies help to realize the overall strategies of the enterprise through the implementation of relevant programs and tactics and the appropriate combination of elements of Marketing Mix. Defining and implementing a strong marketing strategy is almost the single most important factor contributing to the long-term sustainable success of any business (Kotler \& Armstrong, 2014).In a growing competitive marketplace, direct contact with clients is becoming vital. In recent years, VW has developed and expanded its relationship management activities as part of its customer-centric strategic connectivity concept.

Having a good after sales services, the relationship with clients is crucial. Relationships usually involve contacts between two or more people, but people can also have relationships with objects, symbols, and organizations (Hennig-Thurau \& Hansen, 200o). Brand image also have an important role on decision buying. Some studies on brand impact on distribution strategies come to the surface. The findings suggest that while distribution activities can be shared among channel members in a channel selling volume brands, there is a great need for coordination in premium brand sales channels to provide premium values that reflect and justify its price. A premium brand is less affiliated with the local market, its competitive advantage is based on strong brand identification, and the consumer is likely to be attracted more by the premium brand image than by the local trader (Parment, 2008).

Over the past decade, clients have become familiar with the use of various technologies such as websites and other wireless devices to interact with firms. It is becoming common for consumers to use different channels at different stages of their decision-making and purchasing cycle, for example, using websites to obtain information for making offline purchases; in the past they typically acquired all their channel services from a single channel integrated at all stages of their decision-making process (Rangaswamy \& Van Bruggen, 2005).

After sale service (ASS) is regarded as an increasing and important concept in many industries 
for establishing good customer relationships that contribute to increased performance for sustainable results (Loomba, 1998). After-sales services (ASS) are a key strategic tool in the consumer durable products market. They allow manufacturers and retailers to capture more sales and profit ( Murali S.et al., 2015). Omar Sabbaghaa et al. (2015) in their study on impact of quality management and after-sales has cited several authors regarding the after sales vehicle in auto industry: The auto sales business has been experiencing a profit margin shrinkage in line with the continuously prolonged product lifespan and this is motivating auto makers to adjust their focus to the after-sales business as it is becoming a remarkable profit source for both the manufacturers and the dealers (Aboltins and Rivza, 2014). For instance, the current after-sales market is up to five times larger than the new product market (Bundschuh and Dezvane, 2003), whilst the turnover of the original purchase can be tripled during the product lifespan by investing in after-sales services (Wise and Baumgartner, 1999)".

Pricing strategy of every company should be based on the attempt to lower the cost while not decreasing the quality of the vehicle. Teli, S.N. et al. (2014) concluded that: "A properly understood and managed quality cost system will aid organization in realizing cost savings while avoiding some of the serious pitfalls that can accompany cost cutting: decreases in product or service quality, increased customer dissatisfaction, added rework costs or simple shifts in costs from one area to another".

K. Sudhir (2001) stated that: "In a competitive marketplace, the effectiveness of any element of the marketing mix is determined not only by its absolute value, but also by its relative value with respect to the competition. For example, the effectiveness of a price cut in increasing demand is critically related to competitors' reaction to the price change. Managers therefore need to know the nature and extent of competitive reactions".

\section{Research Question and Hypothesis}

The aim of this study is to analyze the role of after-sales services and pricing as determinants on buying decision in automotive industry in Kosovo. To obtain the best results out of it, the main research question and hypothesis has been raised;

Research question: Are the after-sales services and pricing main dominants to determine the customer buying decision?

Hypothesis: After-sales services and price of automobile play dominant role in customer buying decision for specific brand of automobile.

\section{Research Methodology}

Empirically this research is about the determinants that affects decision buying in Kosovo, particularly automobile brands represented by Porsche Kosova sh.p.k. VW, Skoda, AUDI, SEAT and Porsche. The research methodology is a qualitative and quantitative: one where the primary data are collected from the automotive representative Porsche Kosova sh.p.k. and secondary data extracted from various publications and reports related to the automotive industry. The data collection was conducted based on the variables influencing the customer decision-making process during the automotive selection process. The data provided by Porsche Kosovo derives from own internal research in Kosovo with 5870 customers over the years 2008-2019.

Semi-structured questionnaire was used as a research instrument. The data was processed, analyzed and presented with the help of SPSS version 20.0 for Windows.

\subsection{Analyses of correspondence}

To verify the research question "Are the after-sales services and pricing the main dominants to determine the customer buying decision" and the Hypothesis - "After-sales services, pricing and performance of the vehicle, play a key role in the consumer decision to purchase a particular brand" 
we have applied the correspondence analysis with the help of which we have grouped the categories of variables (levels) which offered us the opportunity to visualize the relationship between the categories of variables. In the correspondence analysis each level or category is also called a profile. The analysis will provide us with the distance between the profiles and present them on a two dimensional map. In this way we generate a map which enables us to study and identify the profiles that are closest to each other. Whenever we need to study the relationship between the two categorical variables, the correspondence analysis can serve as a complement to the Chi Square test, especially when we have a large number of categories and the contingency table is not very confusing.

\subsection{Results analyses and discussion}

Before we start with the correspondence analysis, the verified assumptions are that both variables are categorical, their categories are disconnected and are not coded with negative numbers in the database. The condition is that every change must have at least three categories, because the maximum number of dimensions is equal to the minimum number of categories minus one. So if a variable has only two categories, the program can generate only one dimension. The program generates indicators for the contribution of each variable to each dimension based on which the researcher can try to level the dimensions. However in most cases the relationship between profiles is more important than the interpretation of dimensions.

All data are represented below in the tables and figures.

Table 1: Porsche Kosova, Sales data $2009-2018$

Model of Porsche Group

\begin{tabular}{clcccc}
\hline \hline & & Frequency & Percent & Valid Percent & Cumulative Percent \\
\hline \multirow{6}{*}{ Valid } & Skoda & 2214 & 37.7 & 37.7 & 37.7 \\
& Seat & 100 & 1.7 & 1.7 & 39.4 \\
& Porsche & 25 & .4 & .4 & 39.8 \\
& VW & 3180 & 54.2 & 54.2 & 94.0 \\
& Audi & 351 & 6.0 & 6.0 & 100.0 \\
& Total & 5870 & 100.0 & 100.0 & \\
\hline \hline
\end{tabular}

Source: Porsche Kosova

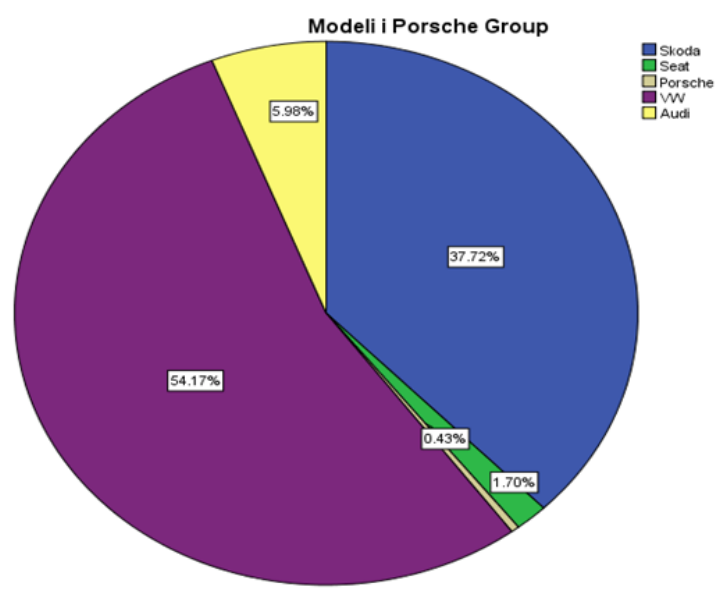

Figure 7: Sales by Porsche Kosova, 2009-2018 in \%

Source: Porsche Kosova 
Table 2: Correspondence Table

Correspondence Table

\begin{tabular}{lcccc}
\hline \hline \multirow{2}{*}{ Model of Porsche Group } & \multicolumn{4}{c}{ Buyers decision } \\
\cline { 2 - 5 } & After sales service & Price & Performance & Active Margin \\
\hline Skoda & 944 & 983 & 287 & 2214 \\
Seat & 58 & 28 & 14 & 100 \\
Porsche & 0 & 5 & 20 & 25 \\
VW & 1537 & 1315 & 328 & 3180 \\
Audi & 93 & 133 & 125 & 351 \\
Active Margin & 2632 & 2464 & 774 & 5870 \\
\hline \hline
\end{tabular}

Source: Author's calculation

From the Table 2, we could notice that 944 Skoda buyers stated that they made the purchase decision due to after sales services, 983 for price reasons and 287 for performance reasons. Whereas, Seat brand, 58 for after sales services, 28 for price reasons, 14 for performance reasons. Porsche brand o for after sales service, 5 for price, and 20 for performance. Brand VW 1537 for after sales service, 1315 for price, 328 for performance reasons. Audi brand, 93 for after sales service, 133 for price and 125 for performance.

Table 3: Division by variables in $\%$

\begin{tabular}{lcccc}
\multicolumn{5}{c}{ Row Profiles } \\
\hline \hline \multirow{2}{*}{ Model of Porsche Group } & \multicolumn{4}{c}{ Buyer decision } \\
\cline { 2 - 5 } & After sales service & Price & Performance & Active Margin \\
\hline Skoda & .426 & .444 & .130 & 1.000 \\
Seat & .580 & .280 & .140 & 1.000 \\
Porsche & .000 & .200 & .800 & 1.000 \\
VW & .483 & .414 & .103 & 1.000 \\
Audi & .265 & .379 & .356 & 1.000 \\
Mass & .448 & .420 & .132 & \\
\hline \hline
\end{tabular}

Source: authors' calculation

After Sales Services: Affected by after sales services are $42 \%$ of Skoda buyers, $58 \%$ of Seat buyers, $48 \%$ of VW's, $26 \%$ of Audi's and o\% of Porsche's. Or $44 \%$ of total buyers are influenced by after sales services. Price: Affected by the price are $44 \%$ of Skoda buyers, $28 \%$ of Seat buyers, $20 \%$ of Porsche buyers, $41 \%$ of VW buyers and $37 \%$ of Audi. In total $\mathbf{4 2} \%$ of buyers are influenced by Price. Performance: Influenced by automotive performance are $13 \%$ of Skoda buyers, $14 \%$ of Seat buyers, $80 \%$ of Porsche buyers, $10 \%$ of VW buyers and $35 \%$ of Audi buyers. In total, $13 \%$ of buyers in the total are impacted by performance.

Table 4: Division by model of vehicles expressed in \%

Column Profiles

\begin{tabular}{lcccc}
\hline \hline \multirow{2}{*}{ Model of Porsche Group } & \multicolumn{3}{c}{ Buying decision } \\
\cline { 2 - 5 } & After sales service & Price & Performance & Mass \\
\hline Skoda & .359 & .399 & .371 & .377 \\
Seat & .022 & .011 & .018 & .017 \\
Porsche & .000 & .002 & .026 & .004 \\
VW & .584 & .534 & .424 & .542 \\
Audi & .035 & .054 & .161 & .060 \\
Active Margin & 1.000 & 1.000 & 1.000 & \\
\hline \hline
\end{tabular}

Source: author's calculation 
Of all Skoda s sold, $35 \%$ stated after-sales services are the main factor influencing the purchase decision, $39 \%$ price and $37 \%$ performance. Of all Seat sales $2 \%$ stated for after sales services, $1 \%$ price and $1 \%$ performance. From Porsche's sales, $0 \%$ after-sales service, $0 \%$ Price, $2 \%$ performance. From VW sales 58\% stated for after sales services, 53\% Price, $42 \%$ Performance. From Audi's Sales $3 \%$ stated for after sales services, $5 \%$ Price, $16 \%$ Performance.

Table 5: Summary of model analyses

\begin{tabular}{|c|c|c|c|c|c|c|c|c|}
\hline \multirow{4}{*}{ Dimension } & \multirow{4}{*}{$\begin{array}{l}\text { Singular } \\
\text { Value }\end{array}$} & \multirow{4}{*}{ Inertia } & \multirow{4}{*}{$\begin{array}{c}\text { Chi } \\
\text { Square }\end{array}$} & & ummary & & & \\
\hline & & & & \multirow{3}{*}{ Sig. } & \multicolumn{2}{|c|}{ Proportion of Inertia } & \multicolumn{2}{|c|}{ Confidence Singular Value } \\
\hline & & & & & \multirow{2}{*}{$\begin{array}{c}\text { Accounted } \\
\text { for }\end{array}$} & \multirow{2}{*}{ Cumulative } & \multirow{2}{*}{$\begin{array}{c}\text { Standard } \\
\text { Deviation }\end{array}$} & Correlation \\
\hline & & & & & & & & 2 \\
\hline 1 & .221 & .049 & & & .944 & .944 & .018 & .092 \\
\hline 2 & .054 & .003 & & & .056 & 1.000 & .012 & \\
\hline Total & & .052 & 303.325 & $.000^{\mathrm{a}}$ & 1.000 & 1.000 & & \\
\hline
\end{tabular}

Source: authors' calculation

The summary of the analysis model, table 5, "Proportion of the Intertia" shows the percentage of variance of the model explained by each dimension. Dimension 1. Explains about $94 \%$ of the total variance while dimension 2 explains about $5 \%$ of the model variance. The Chi Square test tells us that if we have a correlation between the dimensions generated by the analysis and the initial correspondence table no. 13. Since the p-value of the Chi-Square test is less than $5 \%$, we conclude that the correlation exists and we can interpret the correspondence further.

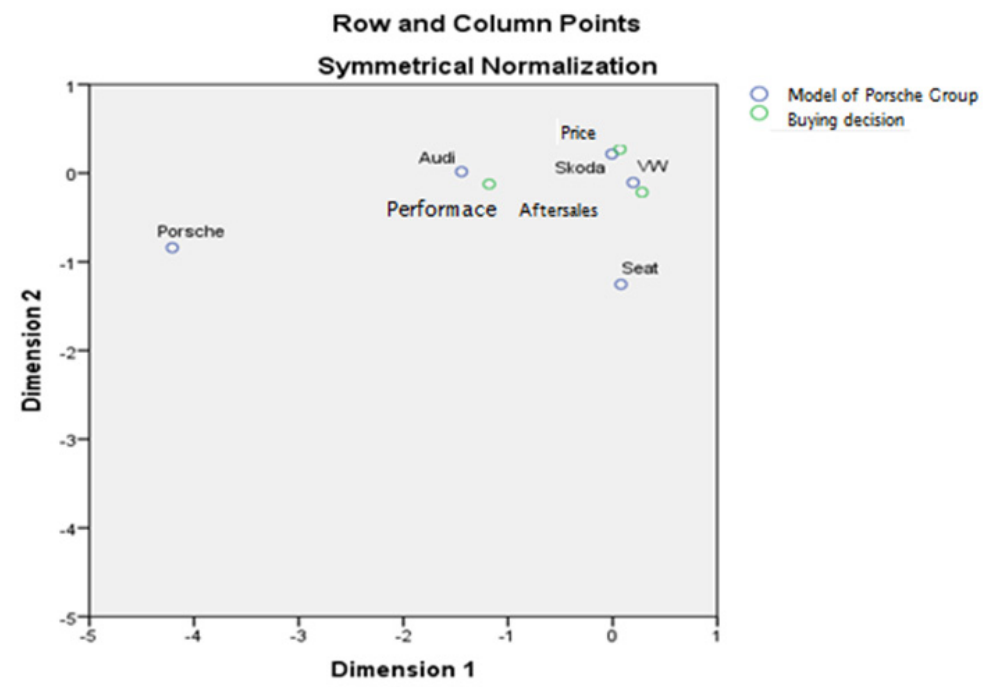

Figure 8: Association between profiles

Source: authors' calculation

From the correspondence analysis we come to the conclusion that most Porsche buyers make the purchase decision for reasons that we do not have in our model and they may be the prestige, design or sporting performance of the vehicle which the variable does not we have taken into account the 
model of our analysis. While Audi model buyers are very close to the performance variable, which means they are largely influenced by the performance that Audi as an automobile offers and this also corresponds to the direction and market segment that the Audi automaker itself claims. The results show that buyers of the Skoda model are largely influenced by Price as the price of Skoda is closest to price and this finding also confirms the target segment of Skoda in the market which is intended to provide value for money. While VW buyers are unlike Skoda buyers even though they are in the middle of Price and after-sales service, they still tend to be more after-sales service than Price, which means that VW buyers are more oriented towards the additional quality and additional services that you are entitled to in addition to price they are more attracted to quality and after sales services. This also confirms that the VW model is intended to provide a mid-quality and popular vehicle among buyers. As Seat model shoppers are closer to the point of sale aftermarket and are distancing themselves from the price at all, they may be attracted by other factors such as design or quality.

\section{Conclusion and Recommendation}

After-sales services, pricing and performance of the vehicle play a key role in the customer's decision to purchase a particular brand is valid and stands but it should be noted that each variable applies to certain models offered by the group. Porsche model buyers' decision is largely influenced by prestige and design, while the Skoda model by Price and aftermarket services. That of VW buyers with most of the aftermarket and price, of Audi performance and price buyers and finally of the Seat most of the aftermarket services. This data is very important for sellers who are difficult to interpret from the spreadsheet.

Based on the results from the research, we could recommend as follows: In the case of Porsche Kosovo it can easily be stated that the merging of several models into a single group enables the company to compete in the market by offering certain products for certain market segments, however it can be argued that a system for managing customer relations like Vehicle Net is missing. Such a system would provide competitive advantage in the market to deepen customer relationships further, especially with the customer segment for which after-sales service is an important part of decision making. Through such a system, the company would facilitate its communication with customers, in the event of a breakdown or any customer complaint the company would be notified of the challenges and problems and take appropriate measures to remedy the problem. Example: In the event of any eventual vehicle breakdown, the Vehicle Net system automatically informs the dealer, assigns the repair term and accurately informs the vehicle user of the cost and time needed to repair the problem in question. With the use of this system, the level of after-sales service would increase, confidence would increase and as a result the level of sales in general would increase. Offering operating leasing has the effect of increasing the demand for new vehicles, given that many key demand clients have all potential costs in a single cist.

\section{References}

Annacchino, M. (2014). The Pursuit of New Product Development (1st ed., pp. 150-350). Burlington: Elsevier Science. Besanko, D. (2013). Economics of strategy (6th ed., pp. 1-56o). Hoboken: John Wiley \& Sons.

Castellion, G. (2007). Manage for Profit, Not for Market Share: A Guide to Greater Profits in Highly Contested Markets by Hermann Simon, Frank F. Bilstein, and Frank Luby. Journal Of Product Innovation Management, 24(4), 404-406. doi: 10.1111/j.1540-5885.2007.00258.x

Chojnacki, K. (200o). Relationship Marketing at Volkswagen. Relationship Marketing, 49-58. doi: 10.1007/978-3662-09745-8_3

Definition of Marketing - American Marketing Association. (2019). Retrieved from https://www.ama.org/thedefinition-of-marketing/

Doleschal, R. (1992). Internationalization and the Reorganization of Production and Marketing in the Volkswagen Corporation. The Internationalization Of The German Political Economy, 1, 90-109. doi: 10.1007/978-1-34922227-8_5 
Dolgui, A., \& Proth, J. (2010). Supply chain engineering (pp. 1-533). Londres: Springer.

Hennig-Thurau, T., \& Hansen, U. (200o). Relationship marketing (1st ed., pp. 49-58). Berlin: Springer.

K. Sudhir (2001), Competitive pricing behavior in the auto market: A structural analysis, Journal Marketing Science 2001 Informs Vol. 20, No. 1, Winter 2001, pp. 42-6o

Kaicker, A., Bearden, W., \& Manning, K. (1995). Component versus bundle pricing. Journal Of Business Research, 33(3), 231-239. doi: 10.1016/0148-2963(94)00072-m

Kotler, P., \& Armstrong, G. (2014). Principles of marketing (14th ed.). Upper Saddle River, N.J.: Pearson.

Kotler, P., \& Keller, K. (2012). Marketing management (12th ed.). Upper Saddle River, N.J.: Pearson/Prentice Hall.

Loomba A. P. S. 1998. Product distribution and service support strategy linkages: en empirical investigation. International Journal of Physical Distribution \& Logistics Management. Vol. 28, No. 2. pp. 143-161

Murali S., Pugazhendhi S.and Muralidharan C. 2015, Evaluation of performance of after sales service - a comparative study involving home appliances, ARPN Journal of Engineering and Applied Sciences,Vol.10, nr.13. pp. 5614-5619

Omar Sabbaghaa, ${ }^{*}$, Mohd Nizam Ab Rahmanb , Wan Rosmanira Ismailc , Wan Mohd Hirwani Wan Hussain, 2015, Impact of Quality Management Systems and After-sales Key Performance Indicators on Automotive Industry: A Literature Review, 6th International Research Symposium in Service management, IRSSM-6 2015, 11-15 August 2015, UiTM Sarawak, Kuching, Malaysia

Parment, A. (2008). Distribution strategies for volume and premium brands in highly competitive consumer markets. Journal Of Retailing And Consumer Services, 15(4), 250-265. doi: 10.1016/j.jretconser.2007.05.006

PORSCHE PRISHTINA. (2019). Retrieved from http://www.porsche-kosova.com/en/

Rangaswamy, A., \& Van Bruggen, G. (2005). Opportunities and challenges in multichannel marketing: An introduction to the special issue. Journal Of Interactive Marketing, 19(2), 5-11. doi: 10.1002/dir.20037

Rekettye, G., \& Liu, J. (2001). Segmenting the Hungarian automobile market brand using perceptual and value mapping. Journal of Targeting, Measurement And Analysis For Marketing, 9(3), 241-253. doi: 10.1057/palgrave.jt.5740019

Rieger, B. (2010). From People's Vehicle to New Beetle: The Transatlantic Journeys of the Volkswagen Beetle. Journal Of American History, 97(1), 91-115. doi: 10.2307/jahist/97.1.91

Sammut-Bonnici, T., \& Channon, D. (2015). Pricing Strategy. Wiley Encyclopedia Of Management, 12, 1-3. doi: 10.1002/9781118785317.weom120162

Scholz, N. (2014). The People's Vehicle: A Global History of the Volkswagen Beetle. German History, 32(4), 667669. doi: 10.1093/gerhis/ghuo40

Stephan Biller Lap Mui Ann Chan David Simchi-Levi Julie Swann, 2002, Dynamic Pricing and the Direct-toCustomer Model in the Automotive Industry: Technical Results and Proofs, E Commerce Journal

Teli, S.N., Majali, V.S., Bhushi, U.M. and Surange, V.G. (2014) 'Impact of poor quality cost in automobile industry', Int. J. Quality Engineering and Technology, Vol. 4, No. 1, pp.21-41.

Wehn, C., Hoppe, C., \& Gregoriou, G. (2013). Rethinking valuation and pricing models (1st ed.). Oxford: Academic Press.

Wells, P. (2010). The Tata Nano, the global 'value' segment and the implications for the traditional automotive industry regions. Cambridge Journal Of Regions, Economy And Society, 3(3), 443-457. doi: 10.1093/cjres/rsqoog 